\title{
Further study on anti-inflammatory oxygenated steroids from the octocoral Dendronephthya griffini
}

\section{Chih-Hua Chao ${ }^{a}$, Zhi-Hong Wen ${ }^{a}$, Jui-Hsin Su ${ }^{a, b}$, I-Ming Chen ${ }^{a}$, Ho-Cheng Huang ${ }^{a, c}$, Chang-Feng Dai ${ }^{d}$, Jyh-Horng Sheu ${ }^{a, b, *}$}

a Department of Marine Biotechnology and Resources, National Sun Yat-sen University, Kaohsiung 804, Taiwan, ROC

b Asia-Pacific Ocean Research Center, National Sun Yat-sen University, Kaohsiung 804, Taiwan, ROC

c Department of Chemical and Materials Engineering, Cheng Shiu University, Kaohsiung 833, Taiwan, ROC

d Institute of Oceanography, National Taiwan University, Taipei 112, Taiwan, ROC

\section{A R T I C L E I N F O}

Article history:

Received 23 April 2008

Received in revised form

13 June 2008

Accepted 17 June 2008

Published on line 1 July 2008

Keywords:

Dendronephthya griffini

Anti-inflammatory

Griffinisterones

\begin{abstract}
A B S T R A C T
Five new steroids, namely griffinisterones F-I (1-4) and griffinipregnone (5) have been isolated from the octocoral Dendronephthya griffini. The structures of these compounds were elucidated by extensive spectroscopic analysis. Compounds 1-3 were found to significantly inhibit the accumulation of the pro-inflammatory iNOS protein of the LPS-stimulated RAW264.7 macrophage cells at $10 \mu \mathrm{M}$. At the same concentrations 2 also could significantly inhibit the accumulation of the pro-inflammatory COX-2 protein.
\end{abstract}

(C) 2008 Elsevier Inc. All rights reserved.

\section{Introduction}

Previous chemical investigations on the octocorals of the genus Dendronephthya have led to the isolation of structurally unique steroids, of which some have been shown to exhibit cytotoxic [1,2] and antifouling [3,4] activities. Recently, we have isolated anti-inflammatory steroids from a Formosan octcoral Dendronephthya griffini [5]. Our continuing chemical investigation on this soft coral has again led to the isolation of five new steroids, griffinisterones F-I (1-4) and griffinipregnone (5). The structures of compounds $1-5$ have been established by extensive spectroscopic analysis, including 2D NMR $\left({ }^{1} \mathrm{H}-{ }^{1} \mathrm{H}\right.$ COSY, HMQC, HMBC, and NOESY) spectroscopy. The ability of 1-3 and 5 to inhibit the expression of the pro-inflammatory iNOS (inducible nitric oxide synthase) and COX-2 (cyclooxygenase-
2) proteins in LPS (lipopolysaccharide)-stimulated RAW264.7 macrophage cells has been evaluated.

\section{Experimental}

\subsection{General procedures}

Optical rotations were measured on a Jasco P-1020 polarimeter. IR spectra were recorded on a Jasco FT/IR-4100 infrared spectrophotometer. The NMR spectra were recorded on Varian Mercury-Plus 300 FT-NMR (or Varian Unity INOVA 500 FT-NMR) instrument at $300 \mathrm{MHz}$ (or $500 \mathrm{MHz}$ ) for ${ }^{1} \mathrm{H}$ (referenced to TMS, $\delta_{\mathrm{H}} 0.0 \mathrm{ppm}$ ) and $75 \mathrm{MHz}$ (or $125 \mathrm{MHz}$ ) for ${ }^{13} \mathrm{C}$ in $\mathrm{CDCl}_{3}$ (referenced to the center line of $\mathrm{CDCl}_{3}, \delta_{\mathrm{C}}$

\footnotetext{
* Corresponding author at: Department of Marine Biotechnology and Resources, National Sun Yat-sen University, Kaohsiung 804, Taiwan, ROC. Tel.: +886 7 5252000x5030; fax: +886 75255020.

E-mail address: sheu@mail.nsysu.edu.tw (J.-H. Sheu). 0039-128X/\$ - see front matter @ 2008 Elsevier Inc. All rights reserved.
} doi:10.1016/j.steroids.2008.06.008 
77.0 ppm). LRMS and HRMS were obtained by ESI on a Bruker APEX II mass spectrometer. Silica gel (60 A, Merck, 230-400 mesh) and C18 reversed phase silica gel (90 , Silicycle, 230-400 mesh) were used for column chromatography. Precoated silica gel plates (Merck Kieselgel $60 \mathrm{~F}_{254} 0.2 \mathrm{~mm}$ ) were used for analytical TLC. High-performance liquid chromatography (HPLC) was performed on a Shimadzu LC-10AT ${ }_{V P}$ apparatus equipped with a Shimadzu SPD-10A $A_{V P}$ UV detector. The columns used in HPLC separation are YMC-Pack Pro C18 (reverse-phase column, $250 \mathrm{~mm} \times 10 \mathrm{~mm}, 5 \mu \mathrm{m}$ ) and Varian Dynamax, Si-60 (normal-phase column, $250 \mathrm{~mm} \times 21.4 \mathrm{~mm}$, $100 \AA, 5 \mu \mathrm{m})$.

\subsection{Animal material}

The octocoral D. griffini was collected unexpectedly by a bottom-trawl net at depths ranged from 200 to $100 \mathrm{~m}$ during an ecological investigation at Taiwan Straight in December 2004. The location was about $60 \mathrm{~km}$ west of Singda Harbor, Kaohsiung County, Taiwan. A voucher specimen was deposited in the Department of Marine Biotechnology and Resources, National Sun Yat-sen University (specimen no. 041206A).

\subsection{Extraction and isolation}

The octocoral (15kg fresh wt) was collected and freezedried. The freeze-dried material was minced and extracted exhaustively with EtOH ( $3 \times 10 \mathrm{~L})$. The organic extract was concentrated to an aqueous suspension and was further partitioned between EtOAc and water. The EtOAc extract $(100 \mathrm{~g})$ was fractionated by open column chromatography on silica gel using $n$-hexane-EtOAc and EtOAc-MeOH mixtures of increasing polarity to yield 19 fractions. Fraction 8, eluted with $n$-hexane-EtOAc (1:1), was further subjected to silica gel column chromatography with gradient elution (n-hexane-acetone, 9:1-4:1) and followed by Sephadex LH-20, using acetone as the mobile phase to afford 2 subfractions (F1-F2). Subfraction F2 was separated by normalphase HPLC, using (n-hexane-EtOAc, 85:15) to afford a residue containing 5 . The final purification was carried out by reverse-phase HPLC $\left(\mathrm{CH}_{3} \mathrm{CN}-\mathrm{H}_{2} \mathrm{O}, 4: 1\right)$ to obtain compound $5(1.8 \mathrm{mg})$. Fraction 9 , eluted with $n$-hexane-EtOAc (2:3), was further subjected to reverse-phase column chromatography with gradient elution $\left(\mathrm{MeOH}-\mathrm{H}_{2} \mathrm{O}, 1: 1-9: 1\right)$ to yield a mixture of 1-4. Subsequently, this mixture was purified by reverse-phase HPLC $\left(\mathrm{CH}_{3} \mathrm{CN}-\mathrm{H}_{2} \mathrm{O}, 82: 18\right)$ to

Table $1-{ }^{13} \mathrm{C}$ NMR spectroscopic data for compounds 1-5

\begin{tabular}{|c|c|c|c|c|c|}
\hline Position & $1^{a}$ & $2^{a}$ & $3^{b}$ & $4^{a}$ & $5^{a}$ \\
\hline 1 & $158.4(\mathrm{CH})^{\mathrm{c}}$ & $158.3(\mathrm{CH})$ & $158.4(\mathrm{CH})$ & $38.5\left(\mathrm{CH}_{2}\right)$ & $82.8(\mathrm{CH})$ \\
\hline 2 & $127.4(\mathrm{CH})$ & $127.4(\mathrm{CH})$ & $127.4(\mathrm{CH})$ & $38.2\left(\mathrm{CH}_{2}\right)$ & $41.6\left(\mathrm{CH}_{2}\right)$ \\
\hline 3 & 200.2 (qC) & 200.2 (qC) & $200.2(q C)$ & $212.1(\mathrm{qC})$ & $210.7(q C)$ \\
\hline 4 & $41.0\left(\mathrm{CH}_{2}\right)$ & $40.9\left(\mathrm{CH}_{2}\right)$ & $40.9\left(\mathrm{CH}_{2}\right)$ & $44.7\left(\mathrm{CH}_{2}\right)$ & $44.8\left(\mathrm{CH}_{2}\right)$ \\
\hline 5 & $44.3(\mathrm{CH})$ & $44.3(\mathrm{CH})$ & 44.3 (CH) & $46.7(\mathrm{CH})$ & $40.3(\mathrm{CH})$ \\
\hline 6 & $27.5\left(\mathrm{CH}_{2}\right)$ & $27.5\left(\mathrm{CH}_{2}\right)$ & $27.5\left(\mathrm{CH}_{2}\right)$ & $28.8\left(\mathrm{CH}_{2}\right)$ & $28.5\left(\mathrm{CH}_{2}\right)$ \\
\hline 7 & $31.4\left(\mathrm{CH}_{2}\right)$ & $31.4\left(\mathrm{CH}_{2}\right)$ & $31.4\left(\mathrm{CH}_{2}\right)$ & $31.8\left(\mathrm{CH}_{2}\right)$ & $31.5\left(\mathrm{CH}_{2}\right)$ \\
\hline 8 & $35.5(\mathrm{CH})$ & $35.5(\mathrm{CH})$ & $35.5(\mathrm{CH})$ & $35.2(\mathrm{CH})$ & $35.5(\mathrm{CH})$ \\
\hline 9 & $50.1(\mathrm{CH})$ & $50.1(\mathrm{CH})$ & $50.1(\mathrm{CH})$ & $53.9(\mathrm{CH})$ & $46.9(\mathrm{CH})$ \\
\hline 10 & $39.0(\mathrm{qC})$ & $39.0(\mathrm{qC})$ & $39.0(\mathrm{qC})$ & $35.7(\mathrm{qC})$ & 40.5 (qC) \\
\hline 11 & $20.8\left(\mathrm{CH}_{2}\right)$ & $20.8\left(\mathrm{CH}_{2}\right)$ & $20.8\left(\mathrm{CH}_{2}\right)$ & $21.0\left(\mathrm{CH}_{2}\right)$ & $20.7\left(\mathrm{CH}_{2}\right)$ \\
\hline 12 & $34.4\left(\mathrm{CH}_{2}\right)$ & $34.4\left(\mathrm{CH}_{2}\right)$ & $34.4\left(\mathrm{CH}_{2}\right)$ & $34.6\left(\mathrm{CH}_{2}\right)$ & $37.4\left(\mathrm{CH}_{2}\right)$ \\
\hline 13 & $47.5(\mathrm{qC})$ & $47.3(\mathrm{qC})$ & $47.3(\mathrm{qC})$ & $47.2(\mathrm{qC})$ & 43.7 (qC) \\
\hline 14 & $56.1(\mathrm{CH})$ & $56.0(\mathrm{CH})$ & $56.0(\mathrm{CH})$ & $55.9(\mathrm{CH})$ & $55.4(\mathrm{CH})$ \\
\hline 15 & $23.3\left(\mathrm{CH}_{2}\right)$ & $23.2\left(\mathrm{CH}_{2}\right)$ & $23.2\left(\mathrm{CH}_{2}\right)$ & $23.4\left(\mathrm{CH}_{2}\right)$ & $24.8\left(\mathrm{CH}_{2}\right)$ \\
\hline 16 & $23.4\left(\mathrm{CH}_{2}\right)$ & $22.4\left(\mathrm{CH}_{2}\right)$ & $22.4\left(\mathrm{CH}_{2}\right)$ & $22.4\left(\mathrm{CH}_{2}\right)$ & $27.2\left(\mathrm{CH}_{2}\right)$ \\
\hline 17 & $59.1(\mathrm{CH})$ & $57.6(\mathrm{CH})$ & $57.3(\mathrm{CH})$ & $57.4(\mathrm{CH})$ & $55.3(\mathrm{CH})$ \\
\hline 18 & $59.0\left(\mathrm{CH}_{2}\right)$ & $59.2\left(\mathrm{CH}_{2}\right)$ & $59.1\left(\mathrm{CH}_{2}\right)$ & $59.2\left(\mathrm{CH}_{2}\right)$ & $12.9\left(\mathrm{CH}_{3}\right)$ \\
\hline 19 & $13.0\left(\mathrm{CH}_{3}\right)$ & $13.0\left(\mathrm{CH}_{3}\right)$ & $13.0\left(\mathrm{CH}_{3}\right)$ & $11.5\left(\mathrm{CH}_{3}\right)$ & $12.8\left(\mathrm{CH}_{3}\right)$ \\
\hline 20 & $74.7(\mathrm{qC})$ & $74.9(\mathrm{qC})$ & $74.9(\mathrm{qC})$ & $75.0(\mathrm{qC})$ & $139.7(\mathrm{CH})$ \\
\hline 21 & $29.0\left(\mathrm{CH}_{3}\right)$ & $26.6\left(\mathrm{CH}_{3}\right)$ & $26.8\left(\mathrm{CH}_{3}\right)$ & $26.8\left(\mathrm{CH}_{3}\right)$ & $114.7\left(\mathrm{CH}_{2}\right)$ \\
\hline 22 & $139.4(\mathrm{CH})$ & $42.3\left(\mathrm{CH}_{2}\right)$ & $44.3\left(\mathrm{CH}_{2}\right)$ & $44.3\left(\mathrm{CH}_{2}\right)$ & \\
\hline 23 & $125.1(\mathrm{CH})$ & $29.4\left(\mathrm{CH}_{2}\right)$ & $22.4\left(\mathrm{CH}_{2}\right)$ & $22.4\left(\mathrm{CH}_{2}\right)$ & \\
\hline 24 & $41.5\left(\mathrm{CH}_{2}\right)$ & $155.9(\mathrm{qC})$ & $39.5\left(\mathrm{CH}_{2}\right)$ & $39.5\left(\mathrm{CH}_{2}\right)$ & \\
\hline 25 & $28.4(\mathrm{CH})$ & $33.8(\mathrm{CH})$ & $27.9(\mathrm{CH})$ & $27.9(\mathrm{CH})$ & \\
\hline 26 & $22.3\left(\mathrm{CH}_{3}\right)$ & $21.9\left(\mathrm{CH}_{3}\right)$ & $22.5\left(\mathrm{CH}_{3}\right)$ & $22.5\left(\mathrm{CH}_{3}\right)$ & \\
\hline 27 & $22.3\left(\mathrm{CH}_{3}\right)$ & $21.9\left(\mathrm{CH}_{3}\right)$ & $22.7\left(\mathrm{CH}_{3}\right)$ & $22.7\left(\mathrm{CH}_{3}\right)$ & \\
\hline 28 & & $106.7\left(\mathrm{CH}_{3}\right)$ & & & \\
\hline $1^{\prime}$ & & & & & $70.6\left(\mathrm{CH}_{2}\right)$ \\
\hline $2^{\prime}$ & & & & & $62.2\left(\mathrm{CH}_{2}\right)$ \\
\hline
\end{tabular}

a Spectra recorded at $125 \mathrm{MHz}$ in $\mathrm{CDCl}_{3}$ at $25^{\circ} \mathrm{C}$.

b Spectra recorded at $75 \mathrm{MHz}$ in $\mathrm{CDCl}_{3}$ at $25^{\circ} \mathrm{C}$.

${ }^{c}$ Multiplicities deduced by DEPT. The chemical shifts referenced to residual signal of $\mathrm{CDCl}_{3}$ at $\delta 77.0 \mathrm{ppm}$. 
Table 2 - ${ }^{1}$ H NMR spectroscopic data for compounds 1-5

\begin{tabular}{|c|c|c|c|c|c|}
\hline Position & $1^{\mathrm{a}}$ & $2^{\mathrm{a}}$ & $3^{b}$ & $4^{\mathrm{a}}$ & $5^{a}$ \\
\hline 1 & $7.15 \mathrm{~d}(10.0)^{\mathrm{c}}$ & $7.15 \mathrm{~d}(10.0)$ & $7.15 \mathrm{~d}(10.2)$ & $2.03 \mathrm{~m} ; 1.35 \mathrm{~m}$ & $3.69 \mathrm{~d}(2.5)$ \\
\hline 2 & $5.86 \mathrm{~d}(10.0)$ & $5.86 \mathrm{~d}(10.0)$ & $5.86 \mathrm{~d}(10.2)$ & $\begin{array}{l}2.39 \mathrm{td}(15.0,6.5) \\
2.30 \mathrm{~m}\end{array}$ & $\alpha: 2.62$ br d (15.0); $\beta: 2.53$ dd $(15.0,3.0)$ \\
\hline \multirow[t]{2}{*}{4} & $\alpha: 2.22$ dd $(17.5,3.5)$ & $\alpha: 2.22$ dd (17.5. 3.5) & $\begin{array}{l}\alpha: 2.21 \mathrm{dd}(18.0, \\
4.2)\end{array}$ & $\begin{array}{l}\alpha: 2.08 \text { ddd }(14.5, \\
4.0,2.5)\end{array}$ & $\alpha: 2.12$ dd $(14.5,13.5)$ \\
\hline & $\beta: 2.37 \mathrm{dd}(17.5,14.5)$ & $\beta: 2.37 \mathrm{dd}(17.5,14.0)$ & $\begin{array}{l}\beta: 2.38 \text { dd (18.0, } \\
14.1)\end{array}$ & $\begin{array}{l}\beta: 2.27 \text { dd (14.5, } \\
14.5)\end{array}$ & $\beta: 2.27$ br d (13.5) \\
\hline 5 & $1.92 \mathrm{~m}$ & $1.92 \mathrm{~m}$ & $1.92 \mathrm{~m}$ & $1.52 \mathrm{~m}$ & $2.08 \mathrm{~m}$ \\
\hline 6 & $1.42 \mathrm{~m}$ & $1.44 \mathrm{~m}$ & $1.43 \mathrm{~m}$ & $1.34 \mathrm{~m}$ & $1.38 \mathrm{~m}$ \\
\hline 7 & $1.72 \mathrm{~m} ; 0.91 \mathrm{~m}$ & $1.73 \mathrm{~m} ; 0.95 \mathrm{~m}$ & $1.72 \mathrm{~m} ; 0.92 \mathrm{~m}$ & $1.70 \mathrm{~m} ; 0.87 \mathrm{~m}$ & $\alpha: 0.96 \mathrm{~m} ; \beta: 1.70 \mathrm{~m}$ \\
\hline 8 & $1.51 \mathrm{~m}$ & $1.52 \mathrm{~m}$ & $1.53 \mathrm{~m}$ & $1.45 \mathrm{~m}$ & $1.43 \mathrm{~m}$ \\
\hline 9 & $1.03 \mathrm{~m}$ & $1.03 \mathrm{~m}$ & $1.03 \mathrm{~m}$ & $0.77 \mathrm{~m}$ & $1.40 \mathrm{~m}$ \\
\hline \multirow[t]{2}{*}{11} & $\alpha: 1.80 \mathrm{~m}$ & $\alpha: 1.80 \mathrm{~m}$ & $\alpha: 1.79 \mathrm{~m}$ & $\alpha: 1.58 \mathrm{~m}$ & $1.47 \mathrm{~m}$ \\
\hline & $\beta: 1.55 \mathrm{~m}$ & $\beta: 1.55 \mathrm{~m}$ & $\beta: 1.54 \mathrm{~m}$ & $\beta: 1.47 \mathrm{~m}$ & $1.38 \mathrm{~m}$ \\
\hline \multirow[t]{2}{*}{12} & $\alpha: 1.07 \mathrm{~m}$ & $\alpha: 1.06 \mathrm{~m}$ & $\alpha: 1.04 \mathrm{~m}$ & $\alpha: 1.00 \mathrm{~m}$ & $\alpha: 1.06 \mathrm{~m}$ \\
\hline & $\beta: 2.68 \mathrm{dt}(12.5,3.5)$ & $\beta: 2.66 \mathrm{dt}(13.0,3.5)$ & $\begin{array}{l}\beta: 2.65 \mathrm{dt}(12.6 \text {, } \\
3.3)\end{array}$ & $\begin{array}{l}\beta: 2.58 \mathrm{dt}(13.0, \\
3.5)\end{array}$ & $\beta: 1.71 \mathrm{~m}$ \\
\hline 14 & $1.22 \mathrm{~m}$ & $1.25 \mathrm{~m}$ & $1.24 \mathrm{~m}$ & $1.17 \mathrm{~m}$ & $1.08 \mathrm{~m}$ \\
\hline \multirow[t]{2}{*}{15} & $\alpha: 1.62 \mathrm{~m}$ & $\alpha: 1.68 \mathrm{~m}$ & $\alpha: 1.66 \mathrm{~m}$ & $\alpha: 1.64 \mathrm{~m}$ & $\alpha: 1.68 \mathrm{~m}$ \\
\hline & $\beta: 1.11 \mathrm{~m}$ & $\beta: 1.16 \mathrm{~m}$ & $\beta: 1.17 \mathrm{~m}$ & $\beta: 1.15 \mathrm{~m}$ & $\beta: 1.19 \mathrm{~m}$ \\
\hline 16 & $1.70 \mathrm{~m}$ & $1.84 \mathrm{~m}$ & $1.78 \mathrm{~m} ; 1.70 \mathrm{~m}$ & $1.78 \mathrm{~m} ; 1.70 \mathrm{~m}$ & $\alpha: 1.80 \mathrm{~m} ; \beta: 1.55 \mathrm{~m}$ \\
\hline 17 & $1.53 \mathrm{~m}$ & $1.53 \mathrm{~m}$ & $1.51 \mathrm{~m}$ & $1.50 \mathrm{~m}$ & $1.98 \mathrm{q}(8.0)$ \\
\hline 18 & $3.65 \mathrm{~d}(12.0) ; 3.59 \mathrm{~d}(12.0)$ & $3.67 \mathrm{~d}(12.0) ; 3.61 \mathrm{~d}(12.0)$ & $\begin{array}{l}3.65 d(12.0) ; 3.59 \\
d(12.0)\end{array}$ & $\begin{array}{l}3.66 \mathrm{~d}(12.0) ; 3.59 \\
d(12.0)\end{array}$ & $0.61 \mathrm{~s}$ \\
\hline 19 & $1.02 \mathrm{~s}$ & $1.02 \mathrm{~s}$ & $1.02 \mathrm{~s}$ & $1.02 \mathrm{~s}$ & $1.02 \mathrm{~s}$ \\
\hline 20 & & & & & 5.76 ddd $(17.5,9.0,8.0)$ \\
\hline 21 & $1.47 \mathrm{~s}$ & $1.41 \mathrm{~s}$ & $1.38 \mathrm{~s}$ & $1.37 \mathrm{~s}$ & $4.97 \mathrm{~d}(9.0) ; 4.96 \mathrm{~d}(17.5)$ \\
\hline 22 & $5.54 \mathrm{~d}(15.5)$ & $1.66 \mathrm{~m} ; 1.55 \mathrm{~m}$ & $1.52 \mathrm{~m} ; 1.32 \mathrm{~m}$ & $1.51 \mathrm{~m} ; 1.30 \mathrm{~m}$ & \\
\hline 23 & 5.50 ddd $(15.5,9.5,6.5)$ & $2.02 \mathrm{t}(8.0)$ & $1.25 \mathrm{~m}$ & $1.24 \mathrm{~m}$ & \\
\hline 24 & $1.91 \mathrm{~m}$ & & $1.16 \mathrm{~m}$ & $1.16 \mathrm{~m}$ & \\
\hline 25 & $1.62 \mathrm{~m}$ & 2.25 sept $(7.0)$ & $1.55 \mathrm{~m}$ & $1.54 \mathrm{~m}$ & \\
\hline 26 & $0.88 \mathrm{~d}(7.5)$ & $1.04 \mathrm{~d}(7.0)$ & $0.88 \mathrm{~d}(6.3)$ & $0.88 \mathrm{~d}(6.5)$ & \\
\hline 27 & $0.88 \mathrm{~d}(7.5)$ & $1.04 \mathrm{~d}(7.0)$ & $0.88 \mathrm{~d}(6.3)$ & $0.88 \mathrm{~d}(6.5)$ & \\
\hline 28 & & $4.77 \mathrm{~s} ; 4.70 \mathrm{~d}(1.5)$ & & & \\
\hline $1^{\prime}$ & & & & & $3.66-3.68^{d} ; 3.39 \mathrm{~m}$ \\
\hline $2^{\prime}$ & & & & & $3.66-3.68^{d}$ \\
\hline $\begin{array}{l}\text { a Spectra } \\
\text { b Spectra } \\
\text { c J values } \\
\text { d Intercha }\end{array}$ & $\begin{array}{l}\text { recorded at } 500 \mathrm{MHz} \text { in } \mathrm{CD} \\
\text { recorded at } 300 \mathrm{MHz} \text { in } \mathrm{CD} \\
\text { (in } \mathrm{Hz} \text { ) in parentheses. } \\
\text { ingeable values. }\end{array}$ & $\begin{array}{l}\mathrm{Cl}_{3} \text { at } 25^{\circ} \mathrm{C} \text {. } \\
\mathrm{Cl}_{3} \text { at } 25^{\circ} \mathrm{C} \text {. }\end{array}$ & & & \\
\hline
\end{tabular}

yield compounds 1 (2.0 mg), 2 (3.0 mg), 3 (4.4 mg), and 4 (1.0 mg).

\subsubsection{Griffinisterone $F(1)$}

Amorphous solid; $[\alpha]^{22} \mathrm{D}^{-80}$ (c $0.30, \mathrm{CHCl}_{3}$ ); IR (KBr) v $v_{\max } 3344$, $1673 \mathrm{~cm}^{-1} ;{ }^{13} \mathrm{C}$ and ${ }^{1} \mathrm{H}$ NMR data, see Tables 1 and 2; ESIMS $\mathrm{m} / \mathrm{z} 437$ [M+Na] $^{+}$; HRESIMS $\mathrm{m} / \mathrm{z} 437.3030$ [M+Na] $^{+}$(calcd. for $\mathrm{C}_{27} \mathrm{H}_{42} \mathrm{O}_{3} \mathrm{Na}$, 437.3031).

\subsubsection{Griffinisterone $G(2)$}

Amorphous solid; $[\alpha]^{22}{ }^{2}-78$ (c 0.30, $\mathrm{CHCl}_{3}$ ); IR (KBr) v $v_{\max } 3329$, $1672 \mathrm{~cm}^{-1} ;{ }^{13} \mathrm{C}$ and ${ }^{1} \mathrm{H}$ NMR data, see Tables 1 and 2; ESIMS $\mathrm{m} / \mathrm{z} 451$ [M+Na] $^{+}$; HRESIMS m/z 451.3190 [M+Na] $^{+}$(calcd. for $\mathrm{C}_{28} \mathrm{H}_{44} \mathrm{O}_{3} \mathrm{Na}$, 451.3188).

\subsubsection{Griffinisterone $\mathrm{H}(3)$}

Amorphous solid; $[\alpha]^{22}{ }^{2}-81$ (c $0.44, \mathrm{CHCl}_{3}$ ); IR (KBr) v $v_{\max } 3311$, $1671 \mathrm{~cm}^{-1} ;{ }^{13} \mathrm{C}$ and ${ }^{1} \mathrm{H}$ NMR data, see Tables 1 and 2; ESIMS $\mathrm{m} / \mathrm{z} 439[\mathrm{M}+\mathrm{Na}]^{+}$; HRESIMS m/z $439.3190[\mathrm{M}+\mathrm{Na}]^{+}$(calcd. for $\mathrm{C}_{27} \mathrm{H}_{44} \mathrm{O}_{3} \mathrm{Na}$, 439.3188).

\subsubsection{Griffinisterone I (4)}

Amorphous solid; $[\alpha]^{22} \mathrm{D}^{-76}$ (c 0.10, $\mathrm{CHCl}_{3}$ ); IR (KBr) v $\max 3308$, $1713 \mathrm{~cm}^{-1} ;{ }^{13} \mathrm{C}$ and ${ }^{1} \mathrm{H}$ NMR data, see Tables 1 and 2; ESIMS

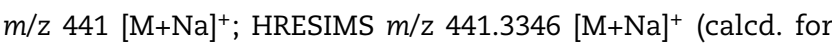
$\mathrm{C}_{27} \mathrm{H}_{46} \mathrm{O}_{3} \mathrm{Na}$, 441.3344).

\subsubsection{Griffinipregnone (5)}

Colorless oil; $[\alpha]^{22} \mathrm{D}^{-56}$ (c 0.18, $\mathrm{CHCl}_{3}$ ); IR (KBr) v $v_{\max } 3438$, $1715 \mathrm{~cm}^{-1} ;{ }^{13} \mathrm{C}$ and ${ }^{1} \mathrm{H}$ NMR data, see Tables 1 and 2; ESIMS $\mathrm{m} / \mathrm{z} 383[\mathrm{M}+\mathrm{Na}]^{+}$; HRESIMS $\mathrm{m} / \mathrm{z} 383.2564[\mathrm{M}+\mathrm{Na}]^{+}$(calcd. for $\mathrm{C}_{23} \mathrm{H}_{36} \mathrm{O}_{3} \mathrm{Na}$, 383.2562).

\subsection{In vitro anti-inflammatory assay}

The anti-inflammatory assay was modified from Ho et al. [6] and Park et al. [7]. Murine RAW264.7 macrophages were 
obtained from the American Type Culture Collection (ATCC, No. TIB-71) and cultured in Dulbecco's modified essential medium (DMEM) containing 10\% heat-inactivated fetal bovine serum, at $37{ }^{\circ} \mathrm{C}$ in a humidified $5 \% \mathrm{CO}_{2}-95 \%$ air incubator under standard conditions. The macrophage cells $\left(3 \times 10^{6}\right)$ plated in $60 \mathrm{~mm}$ culture dishes, were activated by incubation in the medium containing LPS $(0.01 \mu \mathrm{g} / \mathrm{mL}$; Sigma) for $16 \mathrm{~h}$ in the presence or absense of test compounds. Then, cells were washed with ice-cold PBS, lysed in ice-cold lysis buffer, and then centrifuged at $20,000 \times g$ for $30 \mathrm{~min}$ at $4{ }^{\circ} \mathrm{C}$. The supernatant was decanted from the pellet and retained for Western blot analysis. Protein concentrations were determined by the DC protein assay kit (Bio-Rad) modified by the method of Lowry et al. [8] Samples containing equal quantities of protein were subjected to SDS-polyacrylamide gel electrophoresis, and the separated proteins were electrophoretically transferred to polyvinylidene difluoride membranes (PVDF; Immobilon-P, Millipore, $0.45 \mu \mathrm{m}$ pore size). The resultant PVDF membranes were incubated with blocking solution, and then incubated for $180 \mathrm{~min}$ at room temperature with antibodies against inducible nitric oxide synthase (iNOS; 1:1000 dilution; Transduction Laboratories) and cyclooxygenase-2 (COX-2; 1:1000 dilution; Cayman Chemical) proteins. The blots were detected using ECL detection reagents (PerkinElmer, Western Blot Chemiluminescence Reagent Plus) according to the manufacturer instructions. The membranes were reprobed with a monoclonal mouse anti- $\beta$-actin antibody (1:2500, Sigma) as the loading control. For the immunoreactivity data, the intensity of each drug-treated band is expressed as the integrated optical density (IOD), calculated with respect to the average optical density of the corresponding control (treated with LPS only) band. For statistical analysis, all the data were analyzed by a one-way analysis of variance (ANOVA), followed by the Student-Newman-Keuls post hoc test for multiple comparisons. A significant difference was defined as a $P$ value of $<0.05$.

1: $\mathrm{R}=$<smiles>CC(C)C/C=C/C(C)(C)O</smiles>

2: $\mathrm{R}=$<smiles>C=C(CCC(C)(C)O)C(C)C</smiles>

3: $\mathrm{R}=$<smiles>CC(C)CCCC(C)(C)O</smiles><smiles>C=C[C@H]1CC[C@H]2[C@@H]3CC[C@H]4CC(=O)C[C@H](OCCO)[C@]4(C)[C@H]3CC[C@@]21C</smiles>

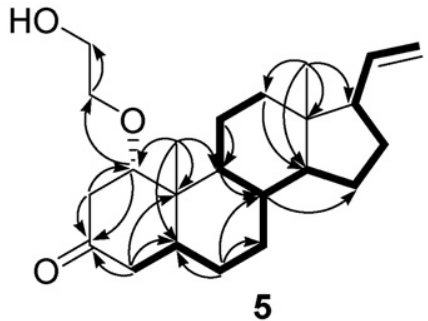

5
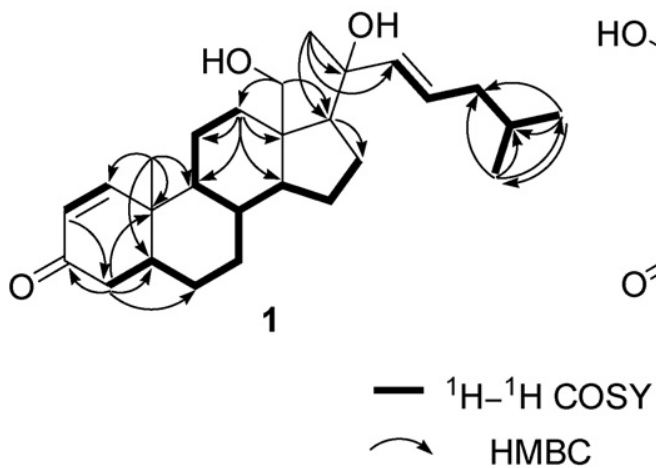

Fig. 1 - Selective ${ }^{1} \mathrm{H}^{-1} \mathrm{H}$ COSY and HMBC correlations of 1 and 5. 


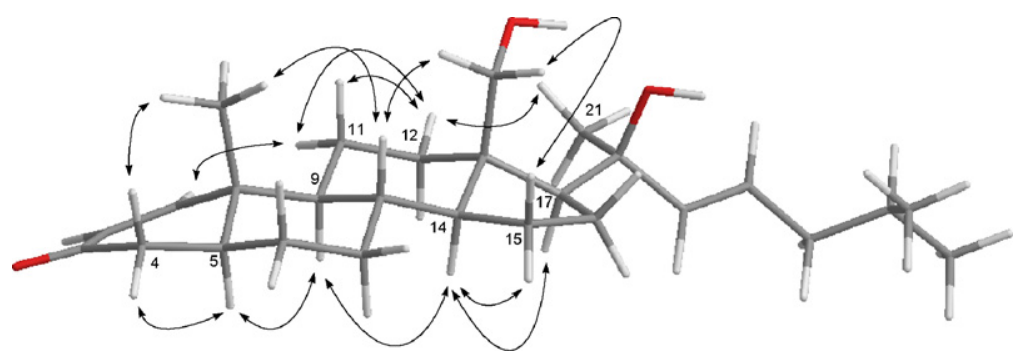

Fig. 2 - Key NOE correlations of 1.

\section{Results and discussion}

The HRESIMS of griffinisterone $F(1)$ exhibited a $[\mathrm{M}+\mathrm{Na}]$ peak at $\mathrm{m} / \mathrm{z} 437.3030$ and established a molecular formula $\mathrm{C}_{27} \mathrm{H}_{42} \mathrm{O}_{3}$, implying seven degrees of unsaturation. The ${ }^{13} \mathrm{C}$ NMR and DEPT spectroscopic data (Table 1) exhibited signals of 27 carbons, including four methyls, nine methylenes, ten methines, and four quaternary carbons. The IR spectrum of 1 revealed the presence of hydroxy $\left(v_{\max } 3344 \mathrm{~cm}^{-1}\right)$, and $\alpha, \beta$ unsaturated carbonyl $\left(v_{\max } 1673 \mathrm{~cm}^{-1}\right)$ groups. The presence of the $\alpha, \beta$-unsaturated ketone also was deduced by the carbon resonances at $\delta_{\mathrm{C}} 200.2(\mathrm{qC}), 158.4(\mathrm{CH})$, and $127.4(\mathrm{CH})[2,4,5]$. The presence of a hydroxymethyl group $\left(\delta_{\mathrm{H}} 3.65\right.$ and 3.59), coupled with signals of one characteristic methyl $\left(\delta_{\mathrm{H}} 1.02,3 \mathrm{H}, \mathrm{s}\right)$ and two olefinic protons $(\delta 7.15,1 \mathrm{H}, \mathrm{d}, J=10.0)$ and $(5.86,1 \mathrm{H}$, $\mathrm{d}, J=10.0)$, suggested that 1 might be 18 -hydroxycholest-1-en3-one derivative [9]. The correlations of ${ }^{1} \mathrm{H}-{ }^{1} \mathrm{H}$ COSY revealed the presence of three consecutive spin systems, as depicted in Fig. 1. The 20-hydroxy group was deduced by a carbon resonance at $\delta 74.7$ (qC, C-20) [9] and by HMBC correlations from the deshielded methyl protons $\mathrm{H}_{3}-21(\delta 1.47,3 \mathrm{H}, \mathrm{s})$ to $\mathrm{C}-17, \mathrm{C}-20$, and $\mathrm{C}-22$. In addition, the presence of a hydroxy group at $\mathrm{C}$ 18 was also confirmed by the $\mathrm{HMBC}$ correlations from $\mathrm{H}_{2}-18$ to $\mathrm{C}-12$ and $\mathrm{C}-17$. The $\mathrm{E}$ geometry of 22,23-double bond was elucidated by NMR data of $\mathrm{H}-22(\delta 5.54, \mathrm{~d}, \mathrm{~J}=15.5 \mathrm{~Hz})$ and $\mathrm{H}-23(\delta 5.50$, ddd, $J=15.5,9.5$, and $6.5 \mathrm{~Hz}$ ). Detailed analysis of the ${ }^{1} \mathrm{H}-{ }^{1} \mathrm{H}$ COSY and HMBC correlations further established the planar structure of 1 , as shown in Fig. 1. The relative stereochemistry of 1 was established by the NOE correlations observed in a NOESY experiment. The NOE correlations between $\mathrm{H}-8$ and both $\mathrm{H}-18 \mathrm{a}$ and $\mathrm{H}_{3}-19$ suggested the $\beta$-position of these protons. Furthermore, $\mathrm{H}-9$ was found to show NOE responses with $\mathrm{H}-5$ and $\mathrm{H}-14$, and $\mathrm{H}-17$ showed correlation with $\mathrm{H}-14$, revealing the $\alpha$-orientation of $\mathrm{H}-5, \mathrm{H}-9, \mathrm{H}-14$ and $\mathrm{H}-17$. The $\beta$ position of 20-OH was also deduced by an NOE correlation of $\mathrm{H}_{3}-21$ with $\mathrm{H}-12 \beta$ [9]. This also was confirmed by examining a molecular model as shown in Fig. 2.

Griffinisterone $\mathrm{G}(2)$ gave a $[\mathrm{M}+\mathrm{Na}]^{+}$peak at $\mathrm{m} / \mathrm{z} 451.3190$ in the HRESIMS. Thus, a molecular formula of $\mathrm{C}_{28} \mathrm{H}_{44} \mathrm{O}_{3}$ was established. The NMR spectra of 2 were almost identical with those of 1 except that the NMR data of 2 showed the absence of 22,23-disubstituted double bond and the presence of an additional $\mathrm{sp}^{2}$ methylene substituent at C-24. Careful inspection of the 2D NMR spectroscopic data of 2 led to the establishment of the same nucleus as that of 1 and the $20 \beta-\mathrm{OH}$ was also deduced by an NOE correlation of $\mathrm{H}_{3}-21$ with $\mathrm{H}-12 \beta$.
Griffinisterone $\mathrm{H}$ (3) was found to possess the molecular formula $\mathrm{C}_{27} \mathrm{H}_{44} \mathrm{O}_{3}$ from the HRESIMS and NMR spectroscopic data. The ${ }^{13} \mathrm{C}$ and ${ }^{1} \mathrm{H}$ NMR spectral data of 3 (Tables 1 and 2) were found to be quite similar to those of 1 , except that the NMR signals appropriate for the 22,23-disubstituted double bond in 1 disappeared and were replaced by a single bond in 3. Thus, the structure of 3 was fully established.

The formula of griffinisterone I (4) was found to be $\mathrm{C}_{27} \mathrm{H}_{46} \mathrm{O}_{3}$, 2 mass units higher than that of 3 , as deduced from HRESIMS and ${ }^{13} \mathrm{C}$ NMR spectroscopic data. By comparison of ${ }^{1} \mathrm{H}$ and ${ }^{13} \mathrm{C}$ NMR spectral data of 4 (Tables 1 and 2) with those of 3, it was found that 4 is the 1,2-dihydro derivative of 3 .

Griffinipregnone (5) was isolated as an amorphous solid. The HRESIMS of 5 established the molecular formula $\mathrm{C}_{23} \mathrm{H}_{36} \mathrm{O}_{3}$, implying six degrees of unsaturation. The ${ }^{13} \mathrm{C}$ NMR and DEPT spectroscopic data (Table 1) showed the presence of 23 carbons, including two methyls, 11 methylenes, seven methines, and three quaternary carbons. The IR spectrum of 5 revealed the presence of hydroxy $\left(v_{\max } 3438 \mathrm{~cm}^{-1}\right)$, and ketocarbonyl groups $\left(v_{\max } 1715 \mathrm{~cm}^{-1}\right)$. The latter was further evidenced by the carbon resonance at $\delta_{C} 210.7$ (qC). In addition, characteristic ${ }^{1} \mathrm{H}$ NMR signals (see Table 2) for two methyls $\left[\delta_{\mathrm{H}} 0.61(3 \mathrm{H}, \mathrm{s})\right.$ and $\left.1.02(3 \mathrm{H}, \mathrm{s})\right]$ and a monosubstituted double bond $\left[\delta_{\mathrm{H}} 5.76(1 \mathrm{H}, \mathrm{ddd}, J=17.5,9.0,8.0 \mathrm{~Hz}), 4.97(1 \mathrm{H}, \mathrm{d}, J=9.0 \mathrm{~Hz})\right.$, $4.96(1 \mathrm{H}, \mathrm{d}, J=17.5 \mathrm{~Hz})]$ suggested the presence of a pregnane skeleton for 5 . Moreover, $\beta$-hydroxyethoxy group possessing two downfield methylenes at $\delta 70.6\left(\mathrm{CH}_{2}, \mathrm{C}-1^{\prime}\right)$ and $62.2\left(\mathrm{CH}_{2}\right.$, $\mathrm{C}-2^{\prime}$ ) were found to be position at $\mathrm{C}-1$ by the HMBC correlations from $\mathrm{H}_{3}-19$ to $\mathrm{C}-1$ and $\mathrm{H}-1$ to $\mathrm{C}-3$ and $\mathrm{C}-\mathrm{1}^{\prime}$. Detailed analyses on ${ }^{1} \mathrm{H}-{ }^{1} \mathrm{H}$ COSY and HMBC correlations (Fig. 1) further established the entire planar structure of 5 unambiguously. The relative stereochemistry and the detailed ${ }^{1} \mathrm{H}$ NMR spectroscopic data of 5 were assigned mainly by the assistance of NOE correlations (Fig. 3). As H-1 exhibited an NOE correla-

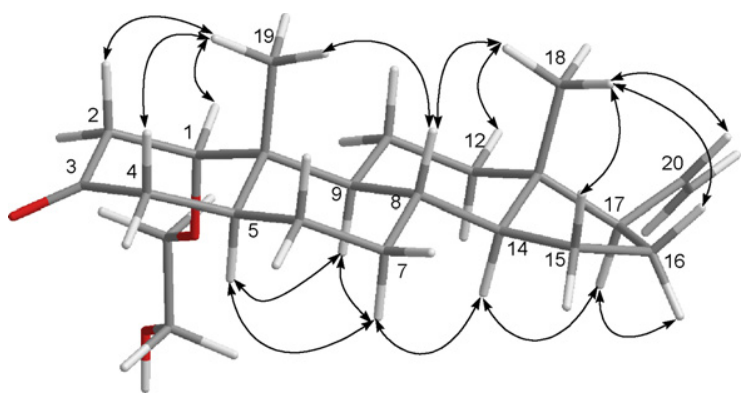

Fig. 3 - Key NOE correlations of 5. 


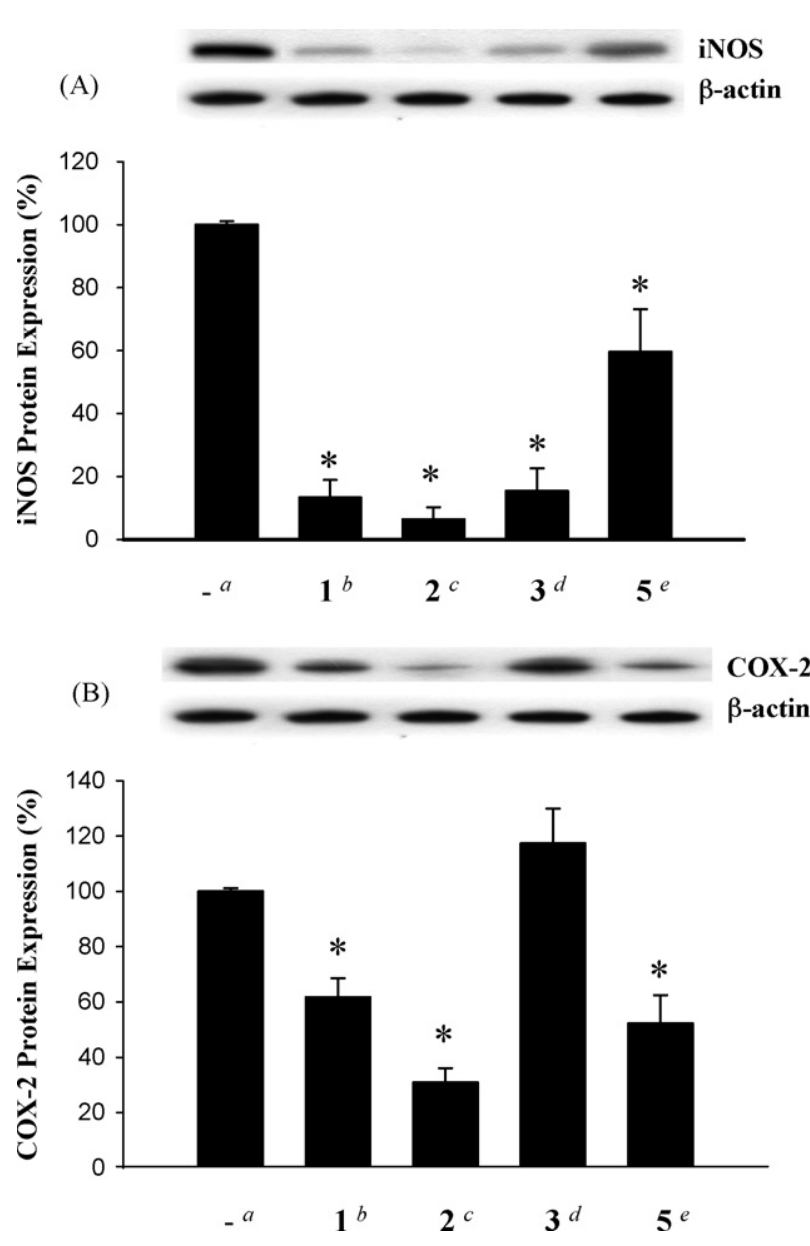

Fig. 4 - Effect of compounds 1-3 and 5 on iNOS and COX-2 protein expression of RAW264.7 macrophage cells by immunoblot analysis. (A) Immunoblots of iNOS and $\beta$-actin; (B) immunoblots of COX-2 and $\beta$-actin. The values are mean \pm S.E.M. $(n=6)$. Relative intensity of the LPS alone stimulated group was taken as $100 \%$. Under the same experimental condition CAPE (caffeic acid phenylethyl ester, $10 \mu \mathrm{M}$ ) reduced the levels of the iNOS and COX-2 to $2.5 \pm 3.7$ and $67.2 \pm 13.4 \%$, respectively. ${ }^{*}$ Significantly different from LPS alone stimulated group $(P<0.05)$. ${ }^{a}$ Stimulated with LPS alone, ${ }^{b}$ stimulated with LPS in the presence of $1(10 \mu \mathrm{M}),{ }^{c}$ stimulated with LPS in the presence of $2(10 \mu \mathrm{M}),{ }^{d}$ stimulated with LPS in the presence of 3 $(10 \mu \mathrm{M}),{ }^{e}$ stimulated with LPS in the presence of $5(10 \mu \mathrm{M})$.

tion with $\mathrm{H}_{3}-19$, it was found that $\mathrm{H}-1$ should be placed on the $\beta$ face. The $\mathrm{H}-14$ signal did not exhibit NOE interaction with $\mathrm{H}_{3}-18$, but instead showed correlations with both $\mathrm{H}-17$ and $\mathrm{H}-7 \alpha$, and $\mathrm{H}-7 \alpha$ showed NOE correlations with $\mathrm{H}-5$ and $\mathrm{H}-9$, suggesting the $\alpha$-orientation of $\mathrm{H}-5, \mathrm{H}-9, \mathrm{H}-14$, and $\mathrm{H}-17$. Furthermore, analysis of the coupling constants of $\mathrm{H}_{2}-2(\delta 2.62$, $1 \mathrm{H}$, br d, $J=15.0 \mathrm{~Hz}, \mathrm{H}-2 \alpha ; 2.53,1 \mathrm{H}, \mathrm{dd}, J=15.0,3.0 \mathrm{~Hz}, \mathrm{H}-2 \beta)$ also confirmed the equitorial, and thus the $\beta$ orientation of $\mathrm{H}$ 1. On the basis of above observations, the structure of 5 was determined unambiguously.
The in vitro anti-inflammatory effect of the sterones 1-3 and 5 was tested. In this assay, the up-regulation of the pro-inflammatory iNOS and COX-2 proteins of the LPSstimulated RAW264.7 macrophage cells was evaluated using the immunoblot analysis. At a concentration of $10 \mu \mathrm{M}$, compounds 1,2 , and 5 could reduce the levels of the iNOS to $13.4 \pm 5.6,6.5 \pm 3.8$, and $59.6 \pm 13.6 \%$, respectively, and COX-2 to $61.7 \pm 6.9,31.5 \pm 5.1$, and $52.3 \pm 10.2 \%$, respectively, relative to the control cells stimulated with LPS only (Fig. 4). At the same concentration, metabolite 3 did not inhibit the COX-2 expression (117.4 $\pm 12.5 \%)$, but could significantly reduce iNOS expression $(15.4 \pm 7.2 \%)$ by LPS treatment.

\section{Acknowledgments}

Financial support was provided by Ministry of Education (96C031702) and National Science Council of Taiwan (NSC 952113-M-110-011-MY3) awarded to J.-H. Sheu.

\section{Appendix A. Supplementary data}

Supplementary data associated with this article can be found, in the online version, at doi:10.1016/j.steroids.2008.06.008.

REFERENCES

[1] Yoshikawa K, Kanekuni S, Hanahusa M, Arihara S, Ohta T. Polyhydroxylated sterols from the octocoral Dendronephthya gigantean. J Nat Prod 2000;63:670-2.

[2] Duh C-Y, El-Gamal AAH, Song P-Y, Wang S-K, Dai C-F. Steroids and sesquiterpenoids from the soft coral Dendronephthya gigantean and Lemnalia cervicorni. J Nat Prod 2004;67: 1650-3.

[3] Tomono Y, Hirota H, Fusetani N. Isogosterones A-D, antifouling 13,17-secosteroids from an octocoral Dendronephthya sp. J Org Chem 1999;64:2272-5.

[4] Tomono Y, Hirota H, Imahara Y, Fusetani N. Four new steroids from two octocorals. J Nat Prod 1999;62:1538-41.

[5] Chao C-H, Wen Z-H, Chen I-M, Su J-H, Huang H-C, Chiang MY, et al. Anti-inflammatory steroids from the octocoral Dendronephthya griffini. Tetrahedron 2008;64: 3554-60.

[6] Ho F-M, Lai C-C, Huang L-J, Kuo T-C, Chao C-M, Lin W-W. The anti-inflammatory carbazole, LCY-2-CHO, inhibits lipopolysaccharide-induced inflammatory mediator expression through inhibition of the p38 mitogen-activated protein kinase signaling pathway in macrophages. $\mathrm{Br} \mathrm{J}$ Pharmacol 2004;141:1037-47.

[7] Park E-K, Shin Y-W, Lee H-U, Kim S-S, Lee Y-C, Lee B-Y, et al. Inhibitory effect of ginsenoside Rb1 and compound $\mathrm{K}$ on NO and prostaglandin E2 biosyntheses of RAW264.7 cells induced by lipopolysaccharide. Biol Pharm Bull 2005;28:652-6.

[8] Lowry DH, Rosebrough NJ, Farr AL, Randall RJ. Protein measurement with the Folin phenol reagent. J Biol Chem 1951;193:265-75.

[9] Aiello A, Fattorusso E, Menna M. Five new polar sterols from the black coral Antipathes subpinnata. Steroids 1991;56: 513-7. 